\title{
Mesenchymal Stem Cells with Enhanced Bcl-2 Expression Promote Liver Recovery in a Rat Model of Hepatic Cirrhosis
}

\author{
Shizhu Jin ${ }^{\mathrm{a}}$ Hulun Lib Mingzi Han ${ }^{\mathrm{a}}$ Mengting Ruan ${ }^{\mathrm{a}}$ Zishuai Liu ${ }^{\mathrm{a}}$ Feifei Zhang ${ }^{\mathrm{a}}$ \\ Chunwei Zhang ${ }^{a}$ Yongsub Choi ${ }^{a}$ Bingrong Liu ${ }^{a}$ \\ aDepartment of Gastrointestinal and Hepatology, The Second Affiliated Hospital, Harbin Medical \\ University, Harbin, 'Department of Neurobiology, Neurobiology Key Laboratory, Harbin Medical \\ University, Education Department of Heilongjiang Province, Harbin, China
}

\section{Key Words}

Mesenchymal Stem Cells $\bullet \mathrm{BCl}-2$ gene $\cdot$ Hepatic cirrhosis $\bullet \mathrm{CCl}_{4}$ treated rats

\begin{abstract}
Background/Aims: Mesenchymal stem cell (MSC) transplantation has emerged as an option for the treatment of chronic hepatic cirrhosis, while its therapeutic efficacy could be improved. The $b c l-2$ gene is anti-apoptotic and can help cell survival and proliferation. Therefore, we explored whether transplanted MSCs with enhanced bcl-2 expression may be beneficial in the treatment of experimental cirrhosis in rats. Methods: MSCs were isolated from rat bone marrow, expanded in vitro and transfected with adeno-associated virus (AAV) engineered the $b c l-2$ gene (AAV-bcl-2). Rats with cirrhosis induced by carbon tetrachloride $\left(\mathrm{CCl}_{4}\right)$ were treated with AAV-bcl-2 infected BMSCs-AAV-bcl-2, with the cells traced in vivo post transplantation. Liver pathology and function were evaluated 7, 14, 21, and 28 days post transplantation, respectively. Results: On day 7 post transplantation, the infused AAV-bcl-2 had integrated into the hepatocyte-like cells (HLCs) that expressed albumin (ALB), Cytokeratin 18 (CK18), and hepatocytes nuclear factor 4a (HNF4a). On day 28 post transplantation, rats in the cirrhosis + BMSCs-AAV-bcl-2 group showed the most dense HLCs, highest mRNA and protein levels of ALB, CK18, and HNF4a, compared to the other groups. Their liver function recovered most rapidly in 4 week observation, while histological sign of cirrhosis remained the end of this period. Conclusion: BMSCs over expressing $b c l-2$ gene showed better survival, and enhanced the differentiation into hepatocytes-like cells, and appeared to promote the recovery of liver function in rats with experimental cirrhosis.

\section{Introduction}

Cirrhosis is the end stage of chronic liver disease and characterized by distortion of hepatic cytoarchitecture, formation of regenerative nodules, aberrant angiogenesis and shunts, leading to the loss of liver function with increased probability of hepatocellular 
carcinoma [1-3]. Currently, orthotopic liver transplantation (OLT) remains the most effective treatment for cirrhosis, which, however, is limited in clinical practice because of donor shortage, surgical complications, immunological rejection and high medical costs [4].

Thus, alternative options have been considered for the treatment of cirrhosis in the past decades, with stem cell transplantation appeared promising. In 2000, Theise et al. reported the presence of Y chromosome-positive hepatocytes in autopsied women who had received therapeutic bone marrow transplantation from male donors, suggesting that bone marrow cells may be useful for stem cell therapy $[5,6]$. Indeed, bone marrow-derived mesenchymal stem cells (BMSCs) have been shown to differentiate into hepatocyte-like cells (HLCs) in vitro and in vivo [7-10]. MSCs have advantages including easy acquisition, strong proliferative capacities and ex vivo expansion. Moreover, they have immune-modulatory properties, are able to migrate into damaged tissues, and secret trophic factors such as growth factors and cytokines, which promote the regeneration of injured liver tissue [11-13].

Despite the major advancements mentioned above for MSCs cell therapy, several critical issues and concerns remain. Several lines of evidence suggest that MSCs might promote tumor growth in vivo $[14,15]$, although some other studies report some anti-tumorigenic effects of MSCs [16-19]. The surviving of engrafted human MSCs may be low in normal and acutely injured livers [18]. Thus, researchers have applied genetic modification of MSCs to improve cell survival, in order to counteract liver fibrosis [20], improve the therapeutic effect [21], or attenuate hepatocellular carcinoma [22].

In the present study, we used adeno-associated virus (AAV) as a vector for overexpressing the $b c l$-2 gene in BMSCs. Compared to other virus vectors, adeno-associated virus vector (AVV) has a number of advantages as a gene delivery system, including the lack of any associated disease with a wild type virus $[23,24]$, possible integration of the gene into the host genome $[25,26]$, and ability to transduce non-dividing cells [27]. Here bcl-2 was chosen as it is an apoptosis repressor gene. Overexpression of $b c l-2$ has been shown to protect neuronal cells from death induced by a variety of stimuli, such as trophic factor deprivation, free radical generation and glutamate excitotoxicity [28-31]. Moreover, $b c l-2$ may play a key role in the progression of liver fibrosis as activated human hepatic stellate cells are resistant to most pro-apoptotic stimuli due to $b c l-2$ overexpression [32-34]. Using histological, biochemical and serological measurements, we demonstrate here that administration of BMSCs with $b c l$ 2 overexpression provides enhanced therapeutic effects in a rat model of liver cirrhosis.

\section{Materials and Methods}

\section{Animals and experimental design}

Male Sprague-Dawley rats, at one-month of age in the beginning of the experiment, were purchased from the animal facility of the Second Affiliated Hospital of Harbin Medical University. Animals were housed at constant temperature $\left(23 \pm 2^{\circ} \mathrm{C}\right)$ and humidity $(55 \pm 10 \%)$, with a $12 / 12 \mathrm{hr}$ light/dark illumination cycle and free accesses to food and water. All experimental procedures were performed in accordance with the Guide for the Care and Use of Laboratory Animals set up by the Harbin Medical University Administrative Panel on Laboratory Animal Care.

Carbon tetrachloride $\left(\mathrm{CCl}_{4}\right)$ is commonly used to induce experimental liver cirrhosis in rodents, which recapitulates the histological, biochemical, cellular and molecular changes associated with human live fibrosis [35]. Rats were separated into two groups, the experimental $(n=85)$ and control $(n=5)$ groups, with the former treated with $\mathrm{CCl}_{4}$ (i.p., $50 \%$ in sterilized saline) at $0.5 \mathrm{ml} / 100 \mathrm{~g}$ once a day in 3 successive days. Control rats were injected same volume of sterilized saline. Five $\mathrm{CCl}_{4}$ treated and the control rats were examined at the end of experiment to evaluate the establishment of the model. The remaining 80 rats in the experimental group were randomly divided into the following four sub-groups (each with 20 rats): Cirrhosis + Saline (0.3 ml), Cirrhosis + AVV-bcl-2 (diluted in in $0.3 \mathrm{ml}$ saline, containing $2 \times 10^{11}$ virus particles), Cirrhosis + BMSCs $\left(10^{7}\right.$ cells $/ \mathrm{ml}$, diluted in in $0.3 \mathrm{ml}$ saline), and Cirrhosis + BMSCs-AVV-bcl-2 $\left(10^{7}\right.$ cells $/ \mathrm{ml}$, diluted in in $0.3 \mathrm{ml}$ saline, containing $1-4 \times 10^{11}$ virus particles, averaged around $\left.2 \times 10^{11}\right)$, to assess the effect of cell therapy at day $7,14,21$, or 28 , respectively, after cell transplant. 


\section{Cellular Physiology Cell Physiol Biochem 2016;40:1117-1128 \begin{tabular}{l|l} 
and Biochemistry Published online: December 14, 2016 & $\begin{array}{l}\text { (c) } 2016 \text { The Author(s). Published by S. Karger AG, Basel } \\
\text { www.karger.com/cpb }\end{array}$
\end{tabular}}

Jin et al.: MSCs Modified by Bcl-2 Gene Promote Liver Regeneration

BMSCs isolation and expansion

BMSCs were obtained from 4-week old rats. Bone marrow was acquired by flushing the femoral midshafts with a syringe. After three centrifugations, cells were seeded $\left(5 \times 10^{5} \mathrm{cell} / \mathrm{ml}\right)$ in a $25 \mathrm{~cm}^{2}$ culture flask with DMEM/F12 (Gibco BRL, Grand Island, NY) supplemented with 10\% fetal bovine serum (Gibco BRL) and penicillin $(10,000$ unit, $\mathrm{pH} 7.4)$. Cultures were maintained at $37{ }^{\circ} \mathrm{C}$ with $5 \% \mathrm{CO}_{2}$ and the medium was changed every 3 days to remove non-adherent cells. When the cells reached $80 \%$ confluence, BMSCs were digested with $0.25 \%$ trypsin and $0.1 \%$ EDTA and subsequently passaged.

BMSCs from the second passage (P2) were used for phenotyping analysis. The cells were incubated for 30 min with FITC or PE-labeled monoclonal antibodies against CD29, CD34, CD44, and CD45 (BD Bioscience, San Jose, CA) and analyzed with flow cytometer (BD FACScalibur, San Jose, CA).

\section{Recombinant AVV and infection of BMSCs}

A recombinant AVV expressing human bcl-2 gene (NM_000633) was purchased from Genechem Biotech Inc. (Shanghai, China). The recombinant AAV virions were purified by the company. Also, the ability of this recombinant construct to express $b c l-2$ was assessed by the provider.

The third-passage BMSCs were plated at a density of $10^{5}$ cells per well in six-well culture plates. Twenty-four hours later, AAV-bcl-2 (MOI=1) virion was added and incubated for $4 \mathrm{hr}$ to infect the cells. The cultures were then washed with $10 \mathrm{mM}$ phosphate-buffered saline (PBS, $\mathrm{pH}=7.4$ ) and the culture medium replaced. Parallel control cultures of BMSCs (AAV-BMSCs) were trans-infected with blank vector. Effective trans-infection was confirmed under a microscope (Olympus, Tokyo, Japan) which identified all BMSCsAAV-bcl-2 cells in red color due to the expression of the cherry report gene. Cell cultures for transplantation were checked for viability by trypan blue and viability was $>90 \%$.

\section{Histological and immunohistochemical analyses}

Paraffin-embedded liver tissues were cut into $5 \mathrm{~mm}$-thick sections, which were stained with hematoxylin and eosin. Fibrosis was evaluated using the Laennec fibrosis scoring system [8]. According to this system, a liver specimen may be scored by any number from 0 to 6 , with 0 indicating no definite fibrosis, 1 minimal fibrosis, 2 mild fibrosis, 3 moderate fibrosis, 4 mild but definite cirrhosis, 5 moderate cirrhosis, and 6 severe cirrhosis. For immunohistochemical analysis, liver sections were incubated with primary antibody to albumin (ALB, sc-46293, 1:200; Santa Cruz, Dallas, TX), CK18 (ab133263, 1:200; Abcam, Cambridge, UK), or HNF4 $\alpha$ (ab41898, 1:100; Abcam, Cambridge, UK) at $4^{\circ} \mathrm{C}$ overnight, then washed and incubated with the biotinylated secondary antibody at $22^{\circ} \mathrm{C}$ for $30 \mathrm{~min}$. After several rinses with buffered saline, the sections were incubated with the streptavidin-HRP conjugate solution at $22^{\circ} \mathrm{C}$ for an additional $30 \mathrm{~min}$. Finally, the sections were developed with a solution of $0.03 \%$ DAB and $0.03 \%$ hydrogen peroxide in Tris/HCl-buffered saline (0.05 M, pH=7.6). The images were acquired using a Nikon microscope (Japan) under a high magnification $(40 \times)$ and positively labeled cells were counted.

Analysis of colocalization of transplanted BMSCs with hepatocytic markers

Immunofluorescence was used to identify the transplanted BMSCs and track their potential hepatocyte differentiation. At first, sections were incubated in the blocking solution with 3\% (w/v) bovine serum albumin (BSA), 0.1\% Triton X-100, and 0.05\% Tween-20. Next, the sections were incubated with goat anti-ALB (Santa Cruz; 1:100), rabbit anti-CK18 (Abcam, 1:200), or mouse anti-HNF4 $\alpha$ (Abcam, 1:100) at $4^{\circ} \mathrm{C}$ overnight. After rinses, the sections were incubated with a mixture of FITC- and TRITC-conjugated secondary antibodies for $2 \mathrm{hr}$ at $4^{\circ} \mathrm{C}$. The nuclei were stained with Hoechst. Fluorescent images were obtained and analyzed with a Leica fluorescence microscope (Germany).

\section{Biochemical analysis}

Blood samples were collected at the time points when rats were sacrificed. They were kept at room temperature for $2 \mathrm{hr}$ and then at $4{ }^{\circ} \mathrm{C}$ overnight. At first, blood samples were centrifuged at $3000 \mathrm{rpm}$ for $10 \mathrm{~min}$ for serum separation. All biochemical parameters were measured with a PUZS-300 automatic biochemical analyzer in the Second Affiliated Hospital of Harbin Medical University. Alanine aminotransferase (ALT), aspartate aminotransferase (AST), total bilirubin (TBL), and ALB levels were measured to evaluate liver function. 


\section{Cellular Physiology Cell Physiol Biochem 2016;40:1117-1128

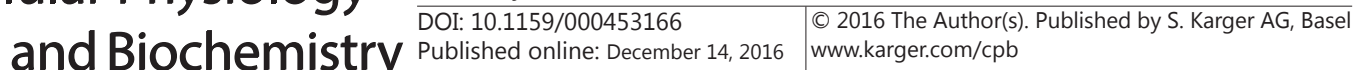 \\ Jin et al.: MSCs Modified by Bcl-2 Gene Promote Liver Regeneration}

Reverse transcription-polymerase chain reaction (RT-PCR)

At the time the animals were killed, liver tissues were collected with total RNA isolated using Trizol reagent (Invitrogen, Carlsbad, CA) according to the manufacturer's protocol. RNA purity and concentration were determined using a spectrophotometer (Ultrospec 2100 pro UV/Visible, Amersham Bioscience, Freiburg, Germany), and cDNA was synthesized from total RNA (1 $\mu \mathrm{g})$ using the GeneAmp RNA PCR Kit (Applied Biosystems, Foster city, CA) with oligo-dT. For RT-PCR, amplification was performed to measure the mRNA levels of ALB, CK18, and HNF4 $\alpha$ using sequence-specific primers (All primers were purchased from Invitrogen). The mRNA levels of the target genes were acquired from the values of the threshold cycle, with $\beta$-actin mRNA as a control.

\section{Western blot assay}

Liver tissues were homogenized using an extraction buffer containing proteinase inhibitors (Jianglai Biotech, Shanghai, China). The lysates were then centrifuged at $12,000 \mathrm{rpm}$ for $10 \mathrm{~min}$ at $4^{\circ} \mathrm{C}$, and the protein concentrations were determined using a protein assay kit (Bio-Rad Laboratories Inc., Hercules, CA). Twenty microgram of proteins was electrophoresed on a 5\% sodium dodecyl sulfate-polyacrylamide gel and then transferred to polyvinylidene difluoride membranes (Millipore, Bedford, MA). The membranes were blocked with 5\% skin milk in Tris-buffered saline containing 0.1\% Tween-20 for $1 \mathrm{hr}$ at room temperature. Then the membranes were incubated with primary antibodies to anti-ALB (Santa Cruz; 1:200), anti-CK18 (Abcam; 1:200), or anti-HNF4 $\alpha$ (Abcam; $1: 200$ ) at $4^{\circ} \mathrm{C}$ overnight, and incubated with the horseradish peroxidaseconjugated secondary antibodies for $1 \mathrm{hr}$ at room temperature. Specific protein bands were developed using an enhanced chemiluminescence detection kit (Amersham, Piscataway, NJ). The membranes were also probed with $\beta$-actin antibody as loading control.

\section{Statistical analysis}

Data were expressed as means \pm standard deviations (SD). Statistical analysis was performed using the Kruskal-Wallis nonparametric analysis, with posthoc tests between individual groups. Statistical analysis was performed using SPSS software (version 20.0, Chicago, IL). P values $<0.05$ was considered significant for all tests.

\section{Results}

Verification of BMSC antigenic phenotype and expression of reporter gene

The BMSCs obtained by bone marrow aspiration and expanded in vitro were small and in micro-sphere shape in the first $24 \mathrm{hrs}$ (Fig. 1A), and increased in number and size in the following 2-3 days (Fig. 1B). The cells of third generation appeared similar to fibroblasts in the spindle-shaped fusiform morphology and expressed the cherry report gene appearing in red under the fluorescent microscope (Fig. 1C). The flow cytometric analysis showed that $>97 \%$ of the expanded BMSCs expressed CD44 (Fig. 1D) and CD29 (Fig. 1E), two typical mesenchymal markers. Moreover, absence of contaminating hematopoietic cells in the BMSCs population was verified by the lack of surface antigens CD45 (Fig. 1F) and CD34 (Fig. $1 \mathrm{G})$ characteristic of hematopoietic progenitor cells.

Verification of CCl4 induced hepatic cirrhosis and functional impairment

$\mathrm{CCl}_{4}$-treated rats surviving one month showed pathological changes of moderate or severe cirrhosis, as evidenced by broad septa and minute nodules (Fig. 2B). In contrast, controls received saline lacked any of these histological changes (Fig. 2A). Higher levels of ALT (Fig. 2C) and AST (Fig. 2D), lower levels of ALB (Fig. 2E), and higher levels of TBL (Fig. $2 \mathrm{~F}$ ) were found in the sera of $\mathrm{CCl}_{4}$-treated rats relative to controls, indicating live function impairments in the former.

Colocalization of bcl-2 gene-modified BMSCs with hepatocyte-like cell markers

To explore a possibility that the infused $b c l-2$ gene-modified BMSCs might differentiate into hepatocyte-like cells in the damaged liver, we performed immunofluorescent staining to 
Fig. 1. Morphology and antigenic phenotyping of the BMSCs. The BMSCs are small and in spherical shape at the first $24 \mathrm{hr}$ culture (A). They increase in number and size in the following 2-3 days of culture (B). The cells of third generation appear similar to fibroblasts in the spindle/fusiform shape and express the cherry report gene in red (C). The flow cytometric analysis shows that $>97 \%$ of the expanded BMSCs expressed CD44 (D) and CD29 (E), but lack of CD45 (F) and CD34 (G).

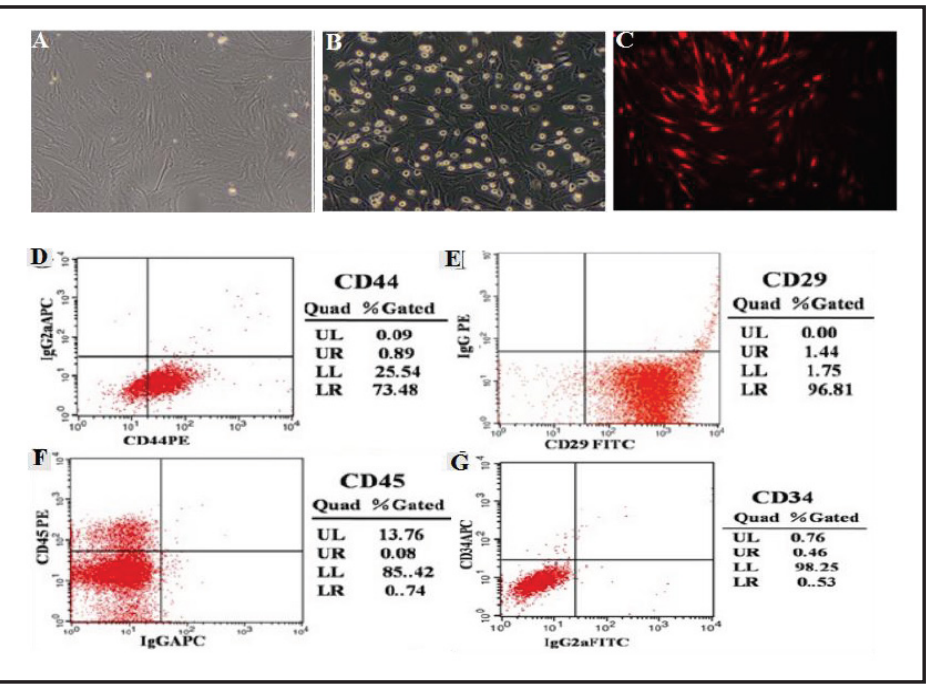

Fig. 2. Carbon tetrachloride induced liver cirrhosis and functional impairments. The liver tissue from normal controls (A) and $\mathrm{CCl}_{4}$-treated rats (B) were histologically stained. Biochemical analyses show higher levels of ALT (C) and AST (D), lower levels of ALB (E), and higher levels of TBL (F) in serum of $\mathrm{CCl}_{4}$-treated rats compared to normal controls. Data are expressed as mean $\pm \mathrm{SD}$; $\mathrm{n}$ $=5$ for each group, $* * \mathrm{p}<0.01$ versus control group.

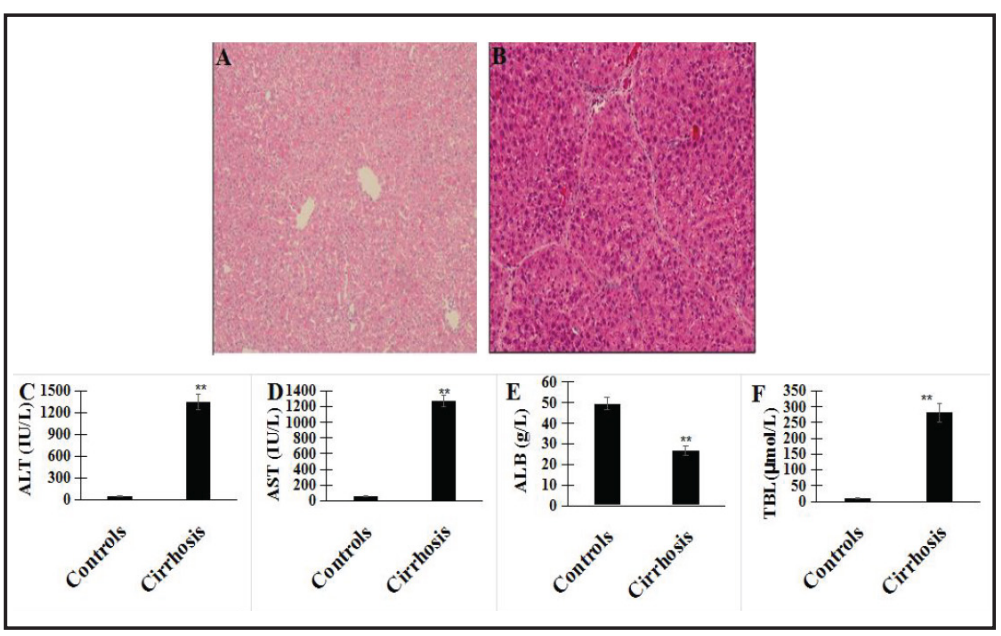

determine colocalization of $b c l-2$ protein with a set of hepatocyte antigen markers, HNF4a, ALB, and CK18, in liver tissue 7 days after the infusion of AVV or $b c l-2$ gene-modified BMSCs. Bcl-2 positive cells co-expressed HNF4a (Fig. 3A-D), CK18 (Fig. 3E-H), and ALB (Fig. 3IL). Moreover, the amounts of double labeled were significantly higher in the BMSCs-AVV$b c l-2$ group compared to the AVV-bcl-2 group (Fig. 3M). In immunohistochemical analysis, ALB-, CK18-, and HNF4a-positive cells appeared mostly frequent in liver tissue of the rats in BMSCs-AVV-bcl-2 group among the 4 groups (Fig. 4A-M). Quantitative analysis indicated that the Cirrhosis+saline group had the fewest ALB-, CK18-, and HNF4a-positive cells, while the Cirrhosis + BMSCs-AVV-bcl-2 group had the most, and the other two groups had middle amounts of cells, with significant statistical difference (Fig. 4M). In parallel with the above immunohistological data, RT-PCR measurements of the corresponding mRNAs (Fig. 5) and Western blot (Fig. 6) analyses of corresponding proteins showed similar trends of differences among the groups.

\section{Bcl-2-modified BMSCs attenuated serological and histological signs of cirrhosis}

The recovery processes of liver function and histology in the animal groups were examined with on days 7, 14, 21, or 28 after infusions of saline, AVV-bcl-2, BMSCs, or BMSCs+AVV-bcl-2. Serum ALB levels progressively increased along the four-week recovery period in all 4 groups, of which the fastest recovery happened in the BMSCs-AVV-bcl-2 group (Table 1). On day 28, serum ALB in this group was comparable to that in the normal healthy 


\section{Cellular Physiology Cell Physiol Biochem 2016;40:1117-1128 \begin{tabular}{ll|l} 
DOI: 10.1159/000453166 & $\begin{array}{l}\text { O 2016 The Author(s). Published by S. Karger AG, Basel } \\
\text { www.karger.com/cpb }\end{array}$
\end{tabular}}

Fig. 3. Colocalization of bcl-2-modified BMSCs with hepatocyte markers. Immunofluorescence was performed on liver sections with antibodies to $b c l-2$, HNF4a, ALB, and CK18 7 days after the infusion of AVV vector or $b c l-2$ gene-modified BMSCs. Liver cells express $b c l$ 2 (red, A, E, I), HNF4a (green, B), CK18 (green, F), and ALB (green, J). Co-localization of $\mathrm{bcl}$ 2 and the latter three proteins are indicated in images $\mathrm{D}, \mathrm{H}$, and $\mathrm{L}$. The histogram (M) shows the statistical comparison (nonparametric test) between the BM-
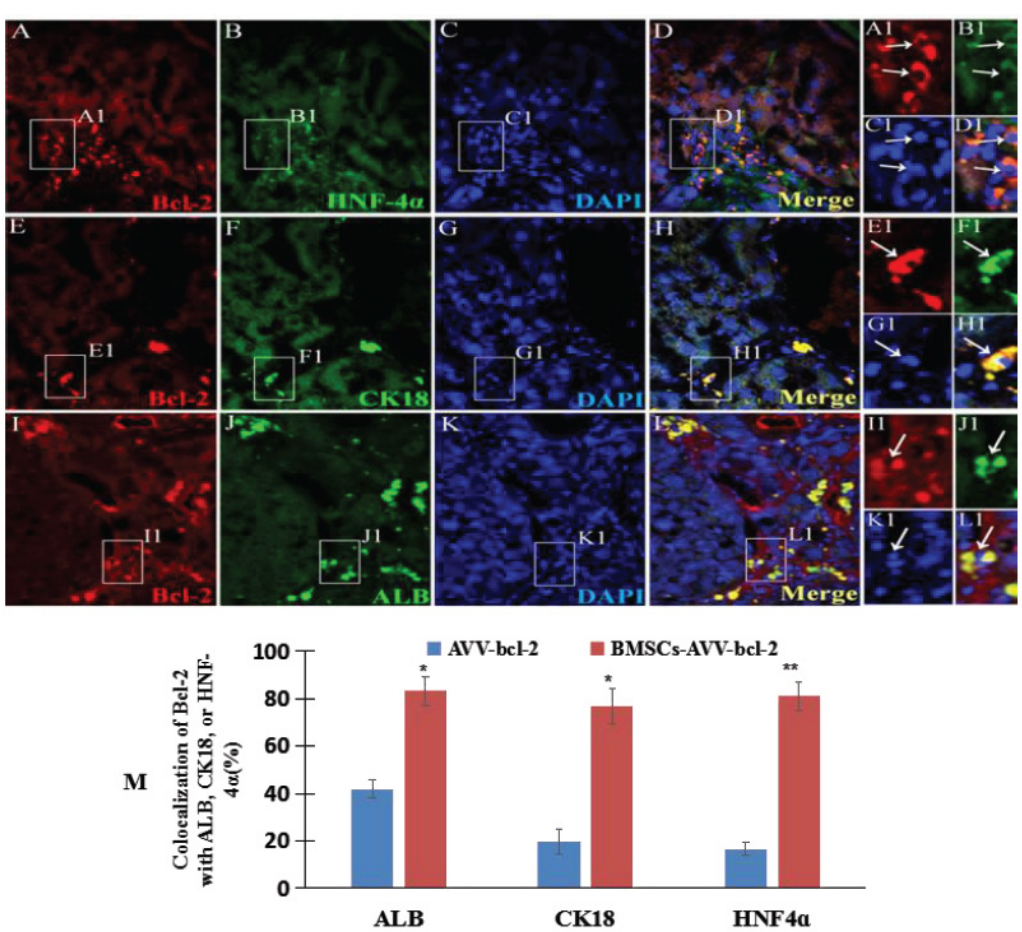

SCs-AVV-bcl-2 and AVV-bcl-2 groups in terms of percentages of the double-stained cells over $b c l-2$ positive cells. Data are expressed as mean $\pm \mathrm{SD} ; \mathrm{n}=5$ for each group, ${ }^{*} \mathrm{p}<0.05$, ${ }^{*} \mathrm{p}<0.01$ versus AVV-bcl-2 group.

Fig. 4. Treatment of $b c l-2$ gene-modified BMSCs enhanced expression of hepatic cellular markers. Immunohistochemical analysis was performed on liver sections with antibodies to ALB, CK18, and HNF4a 28 days after the infusion of saline, AVV-bcl-2, BMSCs, or BMSCsAVV-bcl-2. Representative images A-D show the ALB positive cells in liver sections from the above groups, respectively, E-H CK18 positive cells, I-L HNF4a positive cells. The histogram (M) shows the statistical comparison among the four groups.

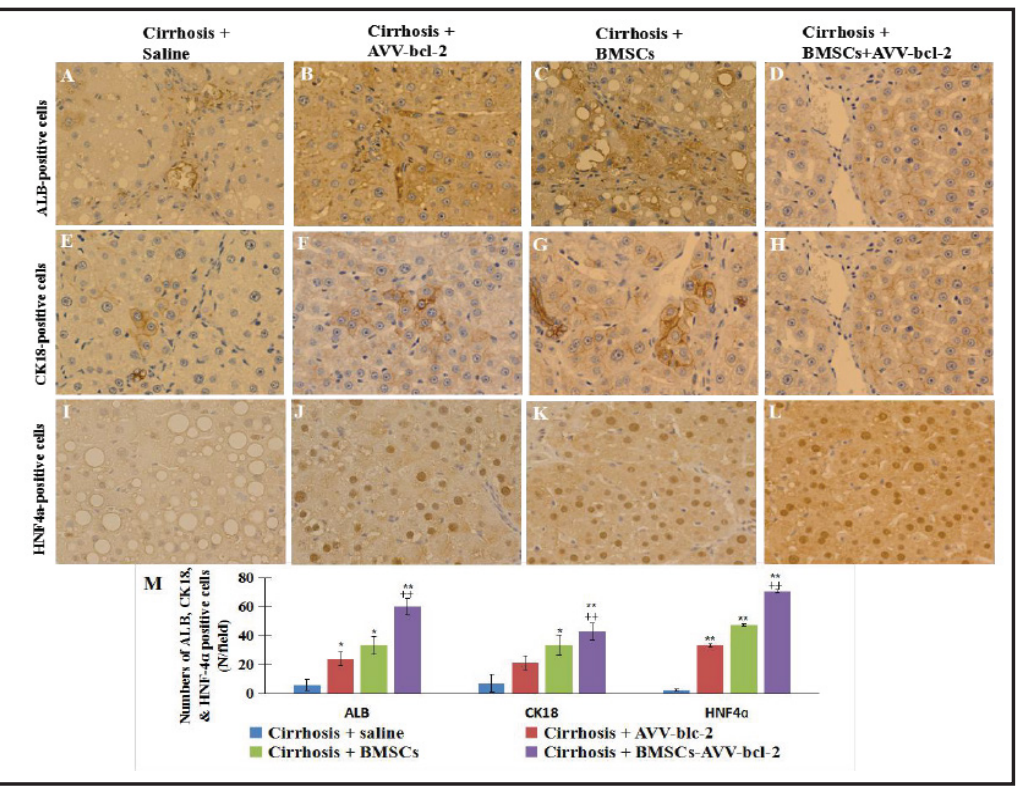

Data are expressed as mean $\pm \mathrm{SD} ; \mathrm{n}=5$ for each group, ${ }^{*} \mathrm{p}<0.05,{ }^{* *} \mathrm{p}<0.01$ versus cirrhosis + saline group. $++\mathrm{p}<0.01$ versus cirrhosis + AVV-bcl-2 group.

rats (46 vs 50). Serum ALT levels progressively decreased along the four-week period in all 4 groups, of which the fastest recovery occurred in the BMSCs-AVV-bcl-2 group (Table 2). On day 28, the serum ALT in this group was close to that in normal healthy rats (58 vs 51). Similarly, levels of serum AST (Table 3) and TBL (Table 4) tended to progressively decrease 


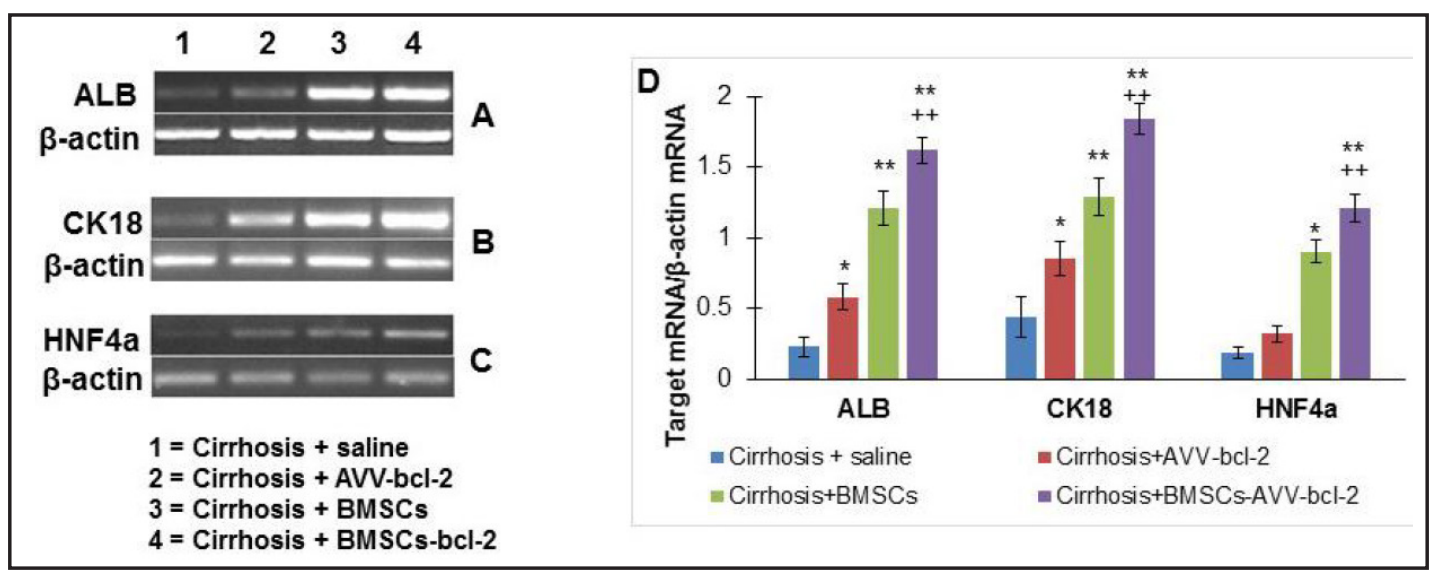

Fig. 5. Treatment of bcl-2 gene-modified BMSCs enhanced mRNA levels of hepatic markers. RT-PCR analysis was performed with liver tissue of the cirrhosis + saline, cirrhosis + AVV-bcl-2, cirrhosis + BMSCs, and cirrhosis + BMSCs-AVV-bcl-2 groups. The levels of mRNAs of ALB, CK18, and HNF4a (A, B and C) show statistically significant difference among the four groups. Data are expressed as mean $\pm S D ; n=5$ for each group, *p $<0.05,{ }^{* *} \mathrm{p}<0.01$ versus cirrhosis + saline group. $++\mathrm{p}<0.01$ versus cirrhosis + AVV-bcl-2 group.

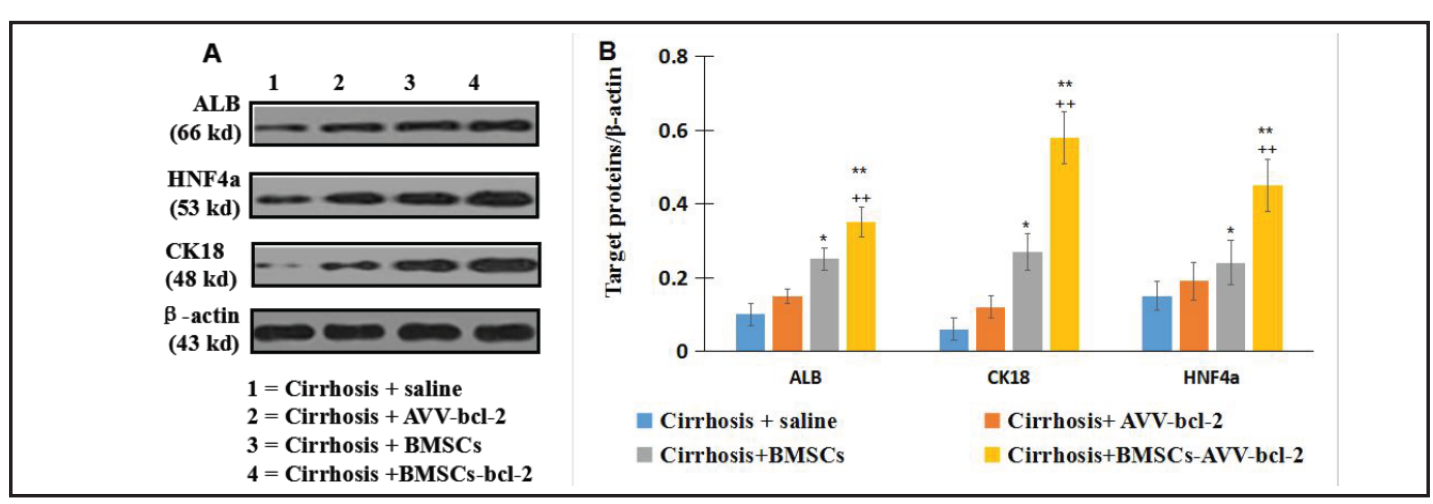

Fig. 6. Treatment of $b c l-2$ gene-modified BMSCs elevated protein levels of hepatic markers. Western blot analysis was performed with liver tissue of the cirrhosis + saline, cirrhosis + AVV-bcl-2, cirrhosis + BMSCs, and cirrhosis + BMSCs-AVV-bcl-2 groups to compare protein levels of ALB, CK18, and HNF4a among these groups. A shows representative western blot images. The histogram (B) shows the statistical comparison among the four groups. Data are expressed as mean $\pm \mathrm{SD} ; \mathrm{n}=5$ for each group, ${ }^{*} \mathrm{p}<0.05,{ }^{* *} \mathrm{p}<0.01$ versus cirrhosis + saline group. $++\mathrm{p}<0.01$ versus cirrhosis + AVV- $b c l-2$ group.

along the 4 week period in all groups, with the fastest recovery in the BMSCs-AVV-bcl-2 group.

We further assessed the extent of cirrhosis histologically among the 4 groups by the Laennec scores. At the end of four week period post $\mathrm{CCl}_{4}$ induction, the recovery of liver cirrhosis was not significant in the cirrhosis + saline group relative to normal control. However, in the other three groups, histological recovery was noted, with the fastest seen in the BMSCs-AVV- $b c l-2$ group, although its recovery was not completely comparable to healthy controls (Table 5).

\section{Discussion}

MSCs are defined as plate-adhering, fibroblast-like cells possessing the capability of self-renewal and differentiation into multiple mesenchymal cell lineages [36]. MSCs are also characterized to express surface markers, such as CD105, CD73 and CD90, but lack of 
Table 1. The comparisons of recovery processes of serum ALB levels (g/L) after liver cirrhosis. Note: Data are expressed as means \pm SD. ${ }^{*} \mathrm{p}<0.05$, ** $\mathrm{p}<0.01$, compared to week 1 in the same group. $+\mathrm{p}<0.05$, compared to the cirrhosis+saline group at the same time point

Table 2. The comparisons of recovery processes of serum ALT levels (IU/L) after liver cirrhosis in rats of the four groups. Note: Data are expressed as means \pm SD. ${ }^{*} \mathrm{p}<0.05$, ** $\mathrm{p}<0.01$, compared to week 1 in the same group. $+\mathrm{p}<0.05$, compared to the cirrhosis+saline group at the same time point

\begin{tabular}{lllll}
\hline & $\begin{array}{l}\text { Cirrhosis+ } \\
\text { Saline }\end{array}$ & $\begin{array}{l}\text { Cirrhosis+ } \\
\text { AVV-bcl-2 }\end{array}$ & $\begin{array}{l}\text { Cirrhosis+ } \\
\text { BMSCs }\end{array}$ & $\begin{array}{l}\text { Cirrhosis+ } \\
\text { BMSCs-AVV- } \\
\text { bcl-2 }\end{array}$ \\
\hline Week 1 & $23.2(4.3)$ & $20.1(3.3)$ & $24.3(3.2)$ & $19.4(3.2)$ \\
Week 2 & $24.9(3.4)$ & $29.3(3.4)^{*}$ & $27.3(4.3)$ & $30.1(2.9)^{*},+$ \\
Week 3 & $30.4(3.9)^{*}$ & $34.4(2.9)^{*}$ & $33.2(3.9)^{*}$ & $37.1(4.3)^{* *},+$ \\
Week 4 & $35.3(2.1)^{*}$ & $39.1(5.4)^{* *}$ & $40.3(5.0)^{* *}$ & $45.5(3.4)^{* *},+$ \\
\hline
\end{tabular}

\begin{tabular}{lllll}
\hline & $\begin{array}{l}\text { Cirrhosis+ } \\
\text { saline }\end{array}$ & $\begin{array}{l}\text { Cirrhosis+ } \\
\text { AVV-bcl-2 }\end{array}$ & $\begin{array}{l}\text { Cirrhosis+ } \\
\text { BMSCs }\end{array}$ & $\begin{array}{l}\text { Cirrhosis+ } \\
\text { BMSCs-AVV- } \\
\text { bcl-2 }\end{array}$ \\
\hline Week 1 & $1521.3(161.0)$ & $1582.1(178.9)$ & $1609.3(167.2)$ & $1643.3(158.9)$ \\
Week 2 & $1129.8(103.2)$ & $789.3(128.3)$ & $892.7(128.1)$ & $469.4(67.2)^{* *},+$ \\
Week 3 & $421.6(39.1)^{*}$ & $253.8(31.1)^{*},+$ & $369.8(23.0)^{*}$ & $89.9(10.1)^{* *},+$ \\
Week 4 & $102.7(12.3)^{* *}$ & $70.6(7.1)^{* *},+$ & $67.5(5.8)^{* *},+$ & $58.1(4.2)^{* *},+$ \\
\hline
\end{tabular}

Table 3. The comparisons of recovery processes of serum AST levels (IU/L) after liver cirrhosis in rats of the four groups. Note: Data are expressed as means \pm SD. ${ }^{*} \mathrm{p}<0.05,{ }^{* *} \mathrm{p}<0.01$, compared to week 1 in the same group. + $\mathrm{p}<0.05$, compared to the cirrhosis + saline group at the same time point

\begin{tabular}{lllll}
\hline & $\begin{array}{l}\text { Cirrhosis+ } \\
\text { saline }\end{array}$ & $\begin{array}{l}\text { Cirrhosis+ } \\
\text { AVV-bcl-2 }\end{array}$ & $\begin{array}{l}\text { Cirrhosis+ } \\
\text { BMSCs }\end{array}$ & $\begin{array}{l}\text { Cirrhosis+ } \\
\text { BMSCs-AVV- } \\
\text { bcl-2 }\end{array}$ \\
\hline Week 1 & $1651.3(198.7)$ & $1492.8(188.9)$ & $1659.3(132.9)$ & $1634.3(198.9)$ \\
Week 2 & $1099.8(103.2)$ & $809.3(89.3)^{*}$ & $792.7(102.9)^{*}$ & $520.4(67.2)^{*,+}$ \\
Week 3 & $397.6(29.0)^{*}$ & $253.8(42.1)^{*}$ & $289.3(23.0)^{* *}$ & $109.3(10.1)^{* *},+$ \\
Week 4 & $117.4(10.9)^{* *}$ & $87.6(8.7)^{* *}$ & $64.5(6.3)^{* *}$ & $38.1(4.6)^{* *},+$ \\
\hline
\end{tabular}

Table 4. The comparisons of recovery processes of serum TBL levels (umol/L) after liver cirrhosis in rats of the four groups. Note: Data are expressed as means \pm SD. $* \mathrm{p}<0.05, * *$ $\mathrm{p}<0.01$, compared to week 1 in the same group. $+\mathrm{p}<0.05$, compared to the cirrhosis+saline group at the same time point

\begin{tabular}{lllll}
\hline & $\begin{array}{l}\text { Cirrhosist } \\
\text { saline }\end{array}$ & $\begin{array}{l}\text { Cirrhosist } \\
\text { AVV-bcl-2 }\end{array}$ & $\begin{array}{l}\text { Cirrhosis+ } \\
\text { BMSCs }\end{array}$ & $\begin{array}{l}\text { Cirrhosis+ } \\
\text { BMSCs-AVV- } \\
\text { bcl-2 }\end{array}$ \\
\hline Week 1 & $238.4(21.0)$ & $249.2(19.4)$ & $251.9(20.1)$ & $229.8(23.0)$ \\
Week 2 & $194.2(12.3)$ & $159.3(14.3)^{*}$ & $172.3(15.9)$ & $121.3(17.2)^{*},+$ \\
Week 3 & $110.2(7.3)^{*}$ & $83.4(7.4)^{*}$ & $72.1(8.3)^{*}$ & $51.4(9.2)^{* *},+$ \\
Week 4 & $23.0(4.5)^{* *}$ & $19.2(3.8)^{* *}$ & $20.0(2.5)^{* *}$ & $14.2(3.2)^{* *},+$ \\
\hline
\end{tabular}

Table 5. The comparisons of recovery processes of liver cirrhosis (Laennec scores) in rats of the four groups. Note: Data are expressed as means \pm SD. $* \mathrm{p}$ $<0.05$, ** $\mathrm{p}<0.01$, compared to week

\begin{tabular}{lllll}
\hline & $\begin{array}{l}\text { Cirrhosis+ } \\
\text { saline }\end{array}$ & $\begin{array}{l}\text { Cirrhosis+ } \\
\text { AVV-bcl-2 }\end{array}$ & $\begin{array}{l}\text { Cirrhosis+ } \\
\text { BMSCs }\end{array}$ & $\begin{array}{l}\text { Cirrhosis+ } \\
\text { BMSCs-AVV- } \\
\text { bcl-2 }\end{array}$ \\
\hline Week 1 & $5.74(0.11)$ & $5.54(0.13)$ & $5.49(0.13)$ & $5.42(0.15)$ \\
Week 2 & $5.71(0.15)$ & $5.39(0.14)$ & $5.22(0.14)+$ & $5.03(0.12)^{*},+$ \\
Week 3 & $5.65(0.12)$ & $5.16(0.11)^{*},+$ & $4.91(0.17)^{*},+$ & $4.58(0.20)^{*},+$ \\
Week 4 & $5.52(0.17)$ & $4.88(0.15)^{*},+$ & $4.48(0.15)^{*},+$ & $4.03(0.17)^{* *},++$ \\
\hline
\end{tabular}

the expression of CD45, CD14 and CD34 [37]. In accordance with these criteria, the BMSCs applied in the present study appear similar to fibroblasts in the spindle-shaped fusiform morphology and can expand well in vitro. They express CD44 and CD29, two typical mesenchymal markers, but not CD45 and CD34. 


\section{Cellular Physiology Cell Physiol Biochem 2016;40:1117-1128 \\ \begin{tabular}{l|l} 
and Biochemistry Published online: December 14, 2016 & $\begin{array}{l}\text { (c) } 2016 \text { The Author(s). Published by S. Karger AG, Basel } \\
\text { www.karger.com/cpb }\end{array}$
\end{tabular} \\ Jin et al.: MSCs Modified by Bcl-2 Gene Promote Liver Regeneration}

Experimental cirrhosis was induced in rats by intraperitoneal injection of $\mathrm{CCl}_{4}$ using established methods [38-40]. It should be noted that $\mathrm{CCl}_{4}$ was given at a relatively high dosage, allowing an induction of liver cirrhosis in a short period. This might account for the severe liver dysfunction and cirrhosis in the $\mathrm{CCl}_{4}$-treated rats in the present study, relative to previous reports [38-40].

Rodent and human MSCs have been shown to differentiate into HLCs possessing the functions of hepatocytes [10,41, 42], which express hepatocyte markers such as AAT, AFP, albumin (ALB), CK18, and HNF4a [43-45]. In accordance, the infused BMSCs in the present study expressed ALB, CK18, and HNF4a. Interestingly, in the present study liver cells in rats infused with only AVV- $b c l-2$ vectors also expressed these markers, indicating a possibility that some of the surviving hepatic cells in the injured liver might be infected by the infused vectors in vivo. Importantly, there were more liver cells that expressed $b c l-2$ together with ALB, CK18 and HNF4a in the rats infused with BMSCs-AVV-bcl-2 relative to animals infused AVV- $b c l-2$ vectors only. Among the four animal groups, the cirrhosis + BMSCs-AVV- $b c l-2$ group had the most, the cirrhosis + saline group the fewest cells showing colocalization, while the other two groups had numbers in-between. Thus, it appears that the $b c l-2$ protein may facilitate a differentiation of BMSCS into functional hepatocytes in injured rat liver. This interpretation was supported by the findings of the highest mRNA and protein levels of hepatic markers in the cirrhosis + BMSCs-AVV-bcl-2 group.

Several in vivo studies have been performed to evaluate the therapeutic potential of MSCs in the context of liver fibrosis and liver function. Jang et al. [8] reported that BMSCs attenuated hepatic fibrosis in thioacetamide-treated rats and improved liver function, as evidenced by the normalized levels of serum ALB, ALT, AST, and TBL. In the present study, we also found that rats in the cirrhosis + saline group showed some automatic serological recovery, however, the recovery in the other 3 groups was significally promoted, with the fastest recovering processes seen in the cirrhosis + BMSCs-AVV-bcl-2 group. Together, infusions of AVV-bcl-2 and BMSCs can accelerate liver recovery following $\mathrm{CCl}_{4}$ injury, and there is a synergistic effect between these two treatments.

A number of mechanisms such as cell transdifferentiation, immunomodulation, antifibrosis and trophic actions are proposed for the therapeutic effect of MSCs in liver fibrosis/ cirrhosis. Although we have not specifically addressed these individual mechanisms, our data can provide some heuristic clues. First, AVV- $b c l-2$ can infect hepatocytes in the injured liver, which might exert some anti-apoptotic effect. Reports have shown that $b c l-2$ can prevent doxorubicin induced apoptosis of human liver cancer cells [46], while staurosporine induced hepacytic apoptosis is associated with down-regulation of $b c l-2$ and bcl-XL [47]. Second, $b c l$ 2 protein expressed in the BMSCs-AVV-bcl-2 complex might help infused BMSCs develop towards liver cells. This interpretation appears in line with other report also showing that enhanced $b c l-2$ expression in grafted neuroepithelial cells promotes the differentiation of these stem cells into enteric neurons [48].

In summary, we demonstrate here that genetic modification with the anti-apoptotic $b c l-2$ gene increases cell survival, and potentially enhances the differentiation of infused BMSCs into HLCs. Such modified BMSCs also promote the recovery of liver function and lessen cirrhotic histology in $\mathrm{CCl}_{4}$-treated rats. The data suggest that transplantation of geneengineered BMSCs may serve an approach for the treatment of cirrhosis.

\section{Acknowledgments}

This work was co-supported by the National Natural Science Foundation of China (Grant \#81370557), the Natural Science Foundation of Heilongjiang Province (Grant \#H201393), the Scientific Project of Health Bureau of Heilongjiang Province (Grant \#2013052) and Heilongjiang Postdoctoral Foundation (Grant \#LBH-Z12111). The authors thank the Lab Center of the Second Affiliated Hospital of Harbin Medical University for providing all experimental equipment and technical assistance. 


\section{Cellular Physiology Cell Physiol Biochem 2016;40:1117-1128

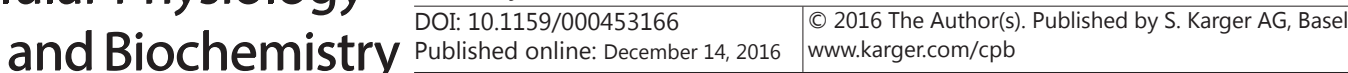 \\ Jin et al.: MSCs Modified by Bcl-2 Gene Promote Liver Regeneration}

Disclosure Statement

The authors declare that they have no conflict of interests.

\section{References}

1 Bolondi L, Gramantieri L: From liver cirrhosis to HCC. Intern Emerg Med 2011;6:93-98.

2 Iredale JP: Cirrhosis: new research provides a basis for rational and targeted treatments. BMJ 2003;327:143-147.

3 Cui L, Hu Y, Bai B, Zhang S: Serum miR-335 Level is Associated with the Treatment Response to TransArterial Chemoembolization and Prognosis in Patients with Hepatocellular Carcinoma. Cell Physiol Biochem 2015;37:276-283.

4 Berardis S, Dwisthi Sattwika P, Najimi M, Sokal EM: Use of mesenchymal stem cells to treat liver fibrosis: current situation and future prospects. World J Gastroenterol 2015;21:742-758.

5 Theise ND, Nimmakayalu M, Gardner R, Illei PB, Morgan G, Teperman L, Henegariu O, Krause DS: Liver from bone marrow in humans. Hepatology 2000;32:11-16.

6 Li B, Shao Q Ji D, Li F, Chen G: Mesenchymal stem cells mitigate cirrhosis through BMP7. Cell Physiol Biochem 2015;35:433-440.

7 Jia S, Liu X, Li W, Xie J, Yang L, Li L: Peroxisome Proliferator-Activated Receptor Gamma Negatively Regulates the Differentiation of Bone Marrow-Derived Mesenchymal Stem Cells Toward Myofibroblasts in Liver Fibrogenesis. Cell Physiol Biochem 2015;37:2085-2100.

8 Jang YO, Kim MY, Cho MY, Baik SK, Cho YZ, Kwon SO: Effect of bone marrow-derived mesenchymal stem cells on hepatic fibrosis in a thioacetamide-induced cirrhotic rat model. BMC Gastroenterol 2014;14:198.

9 Kia R, Sison RL, Heslop J, Kitteringham NR, Hanley N, Mills JS, Park BK, Goldring CE:Stem cell-derived hepatocytes as a predictive model for drug-induced liver injury: are we there yet? Br J Clin Pharmacol 2013; 75:885-896.

10 Terai S, Takami T, Yamamoto N, Fujisawa K, Ishikawa T, Urata Y, Tanimoto H, Iwamoto T, Mizunaga Y, Matsuda T, Oono T, Marumoto M, Burganova G, Fernando Quintanilha L, Hidaka I, Marumoto Y, Saeki I, Uchida K, Yamasaki T, TaniK, Taura Y, Fujii Y, Nishina H, Okita K, Sakaida I: Status and prospects of liver cirrhosis treatment by using bone marrow-derived cells and mesenchymal cells. Tissue Eng Part B Rev 2014;20:206-210.

11 Eom YW, Shim KY, Baik SK: Mesenchymal stem cell therapy for liver fibrosis. Korean J Intern Med 2015;30:580-589.

12 Gao Y, Zhang Y, Lu Y, Wang Y, Kou X, Lou Y, Kang Y: TOB1 Deficiency Enhances the Effect of Bone MarrowDerived Mesenchymal Stem Cells on Tendon-Bone Healing in a Rat Rotator Cuff Repair Model. Cell Physiol Biochem 2016;38:319-329.

13 Ji S, Guo Q, Han Y, Tan G, Luo Y, Zeng F: Mesenchymal stem cell transplantation inhibits abnormal activation of Akt/GSK3 $\beta$ signaling pathway in T cells from systemic lupus erythematosus mice. Cell Physiol Biochem 2012;29:705-712.

14 Djouad F, Plence P, Bony C, Tropel P, Apparailly F, Sany J, Noël D, Jorgensen C: Immunosuppressive effect of mesenchymal stem cells favors tumor growth in allogeneic animals. Blood 2003;102:3837-3844.

15 Yu JM, Jun ES, Bae YC, Jung JS: Mesenchymal stem cells derived from human adipose tissues favor tumor cell growth in vivo. Stem Cells Dev 2008;17:463-473.

16 Khakoo AY, Pati S, Anderson SA, Reid W, Elshal MF, Rovira II, Nguyen AT, Malide D, Combs CA, Hall G, Zhang J, Raffeld M, Rogers TB, Stetler-Stevenson W, Frank JA, Reitz M, Finkel T: Human mesenchymal stem cells exert potent antitumorigenic effects in a model of Kaposi's sarcoma. J Exp Med 2006;203:1235-1247.

17 Qiao L, Xu Z, Zhao T, Zhao Z, Shi M, Zhao RC, Ye L, Zhang X: Suppression of tumorigenesis by human mesenchymal stem cells in a hepatoma model. Cell Res 2008;18:500-507.

18 di Bonzo LV, Ferrero I, Cravanzola C, Mareschi K, Rustichell D, Novo E, Sanavio F, Cannito S, Zamara E, Bertero M, Davit A, Francica S, Novelli F, Colombatto S, Fagioli F, Parola M: Human mesenchymal stem cells as a two-edged sword in hepatic regenerative medicine: engraftment and hepatocyte differentiation versus profibrogenic potential. Gut 2008;57:223-231. 


\section{Cellular Physiology Cell Physiol Biochem 2016;40:1117-1128

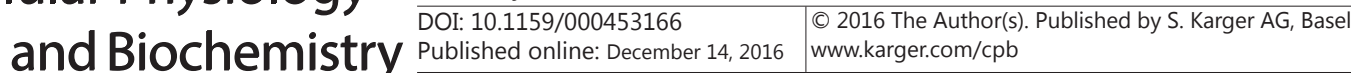

Jin et al.: MSCs Modified by Bcl-2 Gene Promote Liver Regeneration

19 Baertschiger RM, Serre-Beinier V, Morel P, Bosco D, Peyrou M, Clément S, Sgroi A, Kaelin A, Buhler LH, Gonelle-Gispert C: Fibrogenic potential of human multipotent mesenchymal stromal cells in injured liver. PLoS One 2009;4:e6657.

20 Fiore EJ, Bayo JM, Garcia MG, Malvicini M, Lloyd R, Piccioni F, Rizzo M, PeixotoE, Sola MB, Atorrasagasti C, Alaniz L, Camilletti MA, Enguita M, Prieto J, Aquino JB, Mazzolini G: Mesenchymal stromal cells engineered to produce IGF-I by recombinant adenovirus ameliorate liver fibrosis in mice. Stem Cells Dev 2015;24:791801.

21 Kim MD, Kim SS, Cha HY, Jang SH, Chang DY, Kim W, Suh-Kim H, Lee JH: T herapeutic effect of hepatocyte growth factor-secreting mesenchymal stem cells in a rat model of liver fibrosis. Exp Mol Med 2014;46:e110.

22 Xie C, Xie DY, Lin BL, Zhang GL, Wang PP, Peng L, Gao ZL: Interferon- $\beta$ gene-modified human bone marrow mesenchymal stem cells attenuate hepatocellular carcinoma through inhibiting AKT/FOXO3a pathway. Br J Cancer 2013;109:1198-1205.

23 Kotin RM: Prospects for the use of adeno-associated virus as a vector for human gene therapy. Hum Gene Ther 1994;5:793-801.

24 Flotte TR, Carter BJ: Adeno-associated virus vectors for gene therapy. Gene Ther 1995;2:357-362.

25 Kotin RM, Siniscalco M, Samulski RJ, Zhu XD, Hunter L, Laughlin CA, McLaughlin S, Muzyczka N, Rocchi M, Berns KI: Site-specific integration by adeno-associated virus. Proc Natl Acad Sci USA 1990;87:2211-2215.

26 Samulski RJ, Zhu X, Xiao X, Brook JD, Housman DE, Epstein N, Hunter LA: Targeted integration of adenoassociated virus (AAV) into human chromosome 19. EMBO J 1991;10:3941-3950.

27 Podsakoff G, Wong KK Jr, Chatterjee S: Efficient gene transfer into nondividing cells by adeno-associated virus-based vectors. J Virol 1994;68:5656-5666.

28 Lawrence MS, Ho DY, Sun GH, Steinberg GK, Sapolsky RM: Overexpression of Bcl-2 with herpes simplex virus vectors protects CNS neurons against neurological insults in vitro and in vivo. J Neurosci 1996;16:486-496.

29 Antonawich FJ, Federoff HJ, Davis JN: BCL-2 transduction, using a herpes simplex virus amplicon, protects hippocampal neurons from transient global ischemia. Exp Neurol 1999;156:130-137.

30 Yamada M, Natsume A, Mata M, Oligino T, Goss J, Glorioso J, Fink DJ: Herpes simplex virus vector-mediated expression of $\mathrm{Bcl}-2$ protects spinal motor neurons from degeneration following root avulsion. Exp Neurol 2001;168:225-230.

31 Shimazaki K, Urabe M, Monahan J, Ozawa K, Kawai N: Adeno-associated virus vector-mediated bcl-2 gene transfer into post-ischemic gerbil brain in vivo: prospects for gene therapy of ischemia-induced neuronal death. Gene Ther 2000;7:1244-1249.

32 Novo E, Marra F, Zamara E, Valfrè di Bonzo L, Monitillo L, Cannito S, Petrai I, Mazzocca A, Bonacchi A, De Franco RS, Colombatto S, Autelli R, Pinzani M,Parola M: Overexpression of Bcl-2 by activated human hepatic stellate cells: resistance to apoptosis as a mechanism of progressive hepatic fibrogenesis in humans. Gut 2006;55:1174-1182.

33 Zhang X, Tan Z, Wang Y, Tang J, Jiang R, Hou J, Zhuo H, Wang X, Ji J, Qin X, Sun B: PTPRO-associated hepatic stellate cell activation plays a critical role in liver fibrosis. Cell Physiol Biochem 2015;35:885-898.

34 Wei Y, Huang M, Liu X, Yuan Z, Peng Y, Huang Z, Duan X, Zhao T: Anti-fibrotic effect of plumbagin on CCl4lesioned rats. Cell Physiol Biochem 2015;35:1599-1608.

35 Xiao Y, Qu C, Ge W, Wang B, Wu J, Xu L, Chen Y: Depletion of thymosin $\beta 4$ promotes the proliferation, migration, and activation of human hepatic stellate cells. Cell Physiol Biochem 2014;34:356-367.

36 Chan TM, Harn HJ, Lin HP, Chou PW, Chen JY, Ho TJ, Chiou TW, Chuang HM, Chiu SC, Chen YC, Yen SY, Huang MH, Liang BC, Lin SZ: Improved human mesenchymal stem cell isolation. Cell Transplant 2014;23:399-406.

37 Lv FJ, Tuan RS, Cheung KM, Leung VY: Concise review: the surface markers and identity of human mesenchymal stem cells. Stem Cells 2014; 32:1408-1419.

38 Díaz-Gil JJ, Muñoz J, Albillos A, Rúa C, Machín C, García-Cañero R, Cereceda RM, Guijarro MC, Trilla C, Escartín P: Improvement in liver fibrosis, functionality and hemodynamics in CCI4-cirrhotic rats after injection of the Liver Growth Factor. J Hepatol 1999;30:1065-1072.

39 Hou YL, Tsai YH, Lin YH, Chao JC: Ginseng extract and ginsenoside Rb1 attenuate carbon tetrachlorideinduced liver fibrosis in rats. BMC Complement Altern Med 2014;14:415.

40 Huang X, Wang X, Lv Y, Xu L, Lin J, Diao Y: Protection effect of kallistatin on carbon tetrachlorideinduced liver fibrosis in rats via antioxidative stress. PLoS One 2014;9:e88498. 


\section{Cellular Physiology Cell Physiol Biochem 2016;40:1117-1128 \begin{tabular}{l|l|l} 
DOI: 10.1159/000453166 & $\begin{array}{l}\text { O 2016 The Author(s). Published by S. Karger AG, Basel } \\
\text { www.karger.com/cpb }\end{array}$
\end{tabular} \\ Jin et al.: MSCs Modified by $\mathrm{BCl}-2$ Gene Promote Liver Regeneration}

41 Kadota Y, Yagi H, Inomata K, Matsubara K, Hibi T, Abe Y, Kitago M, Shinoda M, Obara H, Itano O, Kitagawa Y: Mesenchymal stem cells support hepatocyte function in engineered liver grafts. Organogenesis 2014;10:268-277.

42 An SY, Han J, Lim HJ, Park SY, Kim JH, Do BR, Kim JH: Valproic acid promotes differentiation of hepatocytelike cells from whole human umbilical cord-derived mesenchymal stem cells. Tissue Cell 2014;46:127135.

43 Banas A, Teratani T, Yamamoto Y, Tokuhara M, Takeshita F, Quinn G, Okochi H, Ochiya T: Adipose tissuederived mesenchymal stem cells as a source of human hepatocytes. Hepatology 2007;46:219-228.

44 Liang XJ, Chen XJ, Yang DH, Huang SM, Sun GD, Chen YP: Differentiation of human umbilical cord mesenchymal stem cells into hepatocyte-like cells by hTERT gene transfection in vitro. Cell Biol Int 2012;36:215-221.

45 Prasajak P, Leeanansaksiri W: Developing a New Two-Step Protocol to Generate Functional Hepatocytes from Wharton's Jelly-Derived Mesenchymal Stem Cells under Hypoxic Condition. Stem Cells Int 2013;2013:762196.

46 Takahashi M, Saito H, Atsukawa K, Ebinuma H, Okuyama T, Ishii H: Bcl-2 prevents doxorubicin-induced apoptosis of human liver cancer cells. Hepatol Res 2003;25:192-201.

47 Giuliano M, Bellavia G, Lauricella M, D'Anneo A, Vassallo B, Vento R, Tesoriere G: Staurosporineinduced apoptosis in Chang liver cells is associated with down-regulation of Bcl-2 and Bcl-XL. Int J Mol Med 2004;13:565-571.

48 Liu W, Yue W, Wu R: Overexpression of Bcl-2 promotes survival and differentiation of neuroepithelial stem cells after transplantation into rat aganglionic colon. Stem Cell Res Ther 2013;4:7. 